\title{
Research on the Influence Factors of Brand Experience on Consumers' Brand Loyalty
}

\author{
Xi Zhang \\ Department of Business Administration, Daejeon University, Daejeon, South Korea \\ Email: zoezhang71@163.com
}

How to cite this paper: Zhang, X. (2019) Research on the Influence Factors of Brand Experience on Consumers' Brand Loyalty. Open Journal of Business and Management, 7, 556-561.

https://doi.org/10.4236/ojbm.2019.72038

Received: March 5, 2019

Accepted: March 25, 2019

Published: March 28, 2019

Copyright $\odot 2019$ by author(s) and Scientific Research Publishing Inc. This work is licensed under the Creative Commons Attribution International License (CC BY 4.0).

http://creativecommons.org/licenses/by/4.0/ (c) (1) Open Access

\begin{abstract}
With the development of society, the world has entered the era of brand internationalization. Brand is the soul of the market, at the same time, brand loyalty, as an important part of brand, has also received attention from many scholars. Customers can clearly measure the brand perception of product through consumption experience, which consists of sensory experience, emotional experience, thinking experience, action experience and related experience. At present, most business models also depend on these five experiences. This paper explores the relationship between these five experiences and brand loyalty through a questionnaire survey based on the example of M-Zone.
\end{abstract}

\section{Keywords}

Brand Experience, Consumers, Loyalty, Factors Research

\section{Introduction}

The product homogenization in today's society is extremely serious, if enterprises only rely on advertising media to enhance their corporate images, it is very unfavorable for enterprises in the long run. Therefore, if enterprises want to get a firm foothold, they must stand higher to get farther perspective. There is no doubt that many enterprises try to make consumers experience their brand firsthand, so that consumers can find brand advantages and enterprises can better develop and expand the market as well as participate in market competition. Therefore, the brand experience has been paid attention and pursued by the businessmen. In order to obtain the customer's recognition and establish emotional contact with customers, enterprises adopt various marketing methods to provide customers with personalized customer experience, thus improving their own competitive advantages. Brand experience is an interactive and individua- 
lized marketing method, in which, brand is the symbol of enterprise goods and services. Fundamentally, it represents people's spiritual or psychological needs, while customers pay more attention to the sensation, feelings and values that a brand can bring to them than to the simple identification of a brand. Therefore, this paper puts forward the hypothesis of influencing brand loyalty based on the previous research results, and uses multiple regression to carry out data statistical analysis based on investigation and research, thus drawing a conclusion.

Due to the late research on brand loyalty in academic circles, the research on dimension of brand loyalty is still in the exploratory stage, and the literature is relatively little, so its research results have not formed a unified view and conclusion. In addition, the research methods used are also very single, mainly taking the research results of Western Psychology on love as the starting point, to constitute their respective research dimensions, and to establish corresponding measurement terms for each dimension. In the economic form of experiential economy, customers stimulate their inner feelings by experiencing the feeling of their favorite brands. The theory of cognition-emotion-behavior in consumer psychology shows that when consumers want to consume a product, they will firstly understand it to form knowledge on the product, and then generate positive and active feelings, and finally take positive actions [1] [2].

Although scholars at home and abroad have different understandings of brand experience, they all agree that brand experience requires interaction between customers and brands. This paper agrees with the definition of Schmitt [3], that is, brand experience is a behavioral response caused by sensation, perception and stimulus related to brand. This definition is concluded by combining the characteristics of brand experience based on Schmitt's [3] understanding of experience, which is more consistent with the connotation of brand experience in this study.

\section{Method}

The main purpose of this paper is to investigate and analyze the relationship between consumer experience and brand loyalty. First of all, the five factors, sensory experience, emotional experience, thinking experience, action experience and related experience, are taken as the influencing factors of brand loyalty. Furthermore, this paper investigates by means of questionnaires, then collects the questionnaires for data analysis, and finally draws the relationship between the two through the survey conclusions. In order to better understand the impact of consumer experience on brand loyalty of a company, the questionnaire is designed according to the five experience modes, each of which has two questions. This paper analyses the data from a total of 80 valid questionnaires [1] [2] [4].

\section{Statistical Analysis Technique}

Based on multiple regression, this paper carries out statistical analysis of data and draws a conclusion. 


\section{Research Results}

\subsection{Sensory Experience and Brand Loyalty}

When investigating what aspects of a brand attract consumers, it is found that staff enthusiasm, business hall decoration and staff wear account for a similar proportion. Similarly, when asked whether a brand has sensory charm, 90\% of people agree with this view (see Figure 1).

\subsection{Emotional Experience and Brand Loyalty}

During the survey, when people were asked how they felt about the brand, 64\% thought "trying to make me like it", and $34 \%$ thought it was very friendly to consumers.

\subsection{Thinking Experience and Brand Loyalty}

The research shows that only $22 \%$ of the three opinions are "arousing my curiosity (Table 1), stimulating my association with certain things, and surprising me with certain ideas", showing that college students do not do too much association and thinking when choosing this brand. A certain brand still has a certain gap in arousing consumers' interest, accounting for only $17 \%$. This data can better prove that college students do not make too much association when choosing this brand, nor do they have great creativity, that is, it is difficult for college students to integrate thinking experience into consumption. It can be seen that the influence of thinking experience on college students' loyalty to the brand is not very significant [4].

\subsection{Related Experience and Brand Loyalty}

According to the research data, $89 \%$ of the students are more likely to contact people who use a certain brand, which shows that college students prefer to join

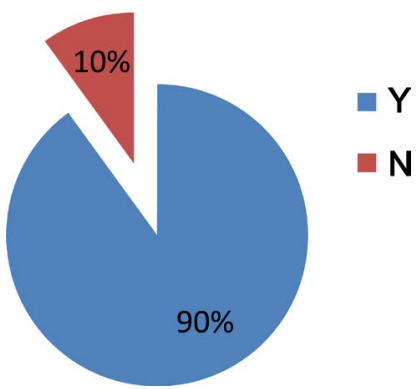

Figure 1. A survey on whether a brand has sensory charm.

Table 1. Survey on the feelings of a brand experience store and brand to consumers.

\begin{tabular}{cc}
\hline Factors & Percentage \\
\hline Arousing my curiosity & $5 \%$ \\
Surprising me with certain ideas & $12 \%$ \\
Stimulating my association with certain things & $5 \%$
\end{tabular}


a certain group, hoping that they can have a sense of belonging and can communicate with people who have similar hobbies. For a brand, its most basic business is to contact others. A brand with different packages for college students on campus makes college students feel their own sense of existence and their own characteristics, so most college students choose to use this brand. It is concluded that related experience can have a positive impact on consumer loyalty [4] [5].

\section{Marketing Strategies of Enhancing Brand Loyalty}

This paper investigates the relationship between consumption experience and brand loyalty. The survey results are mainly applied to enterprises to make the survey meaningful. This paper gives some suggestions and strategies for the long-term development of enterprises on several experiences that have an impact on brand loyalty [6] [7].

Sensory experience is the most basic experience. It creates the sensory impact and achieves the stimulation of consumers through five senses. The initial impression of consumers is affected by it when they come into contact with the brand. Therefore, the shaping of sensory experience requires us to work hard on the outer packaging of products and the consumption environment [7].

The influence of action experience on brand loyalty is also obvious. Consumers are eager to experience the life experience brought by brands through their participation in the consumption process. Therefore, customers must participate in the service process to realize their needs and obtain the required services. Advertising is the most common form of advertising. It must have value. It has to be entertaining in order to be known and accepted by the public. Traditional advertising focuses on the expression of the unique characteristics of the product, paying attention to the selling point of the product. Under the new situation, advertising and publicity will integrate people's experience into the product, replace the single selling point of the product, and enable the consumers to participate into the publicity process, so that customers can get the required action experience.

Related experience will make consumers to have a sense of belonging and have some impulse to join a group or organization. Enterprises should make use of the emotional needs of college students to accumulate related experience. When an individual finds an organization particularly attractive to him, he or she may have the same characteristics as the organization and would like to have a special wish to join the organization. But when he or she cannot join the organization for their own reasons, the attraction of the organization to them will increase exponentially. They will consciously or unconsciously buy some products that conform to the identity or characteristics of the group, so that they can be more like the people of the organization.

Experience marketing comes into being along with experience economy, which emphasizes the contact and participation of customers. As an advanced 
marketing concept, it can be combined with products and services to form new core competitive advantages. In the past, in order to make their products well-known and more effective in marketing, they believed that most customers paid attention to the quality and performance of the products, and they believed that customers would rationally buy each product. The theory of experiential marketing holds that customers not only pay attention to the product performance, but also pay attention to the feeling or experience in the shopping process. In this way, consumers are both emotional and rational.

When experience is applied to economics, experience marketing develops accordingly. In 1970, Toffler, an American futurist, used the term experience in economics. Since then, more and more economists have begun to study experience. At the same time, he believes that after the service economy, another big economic form will emerge, that is, the experience economy, which will occupy the main position in the future.

\section{Conclusion}

This paper analyzes the relationship between college students' consumption experience and brand loyalty through a questionnaire survey on this brand, and draws the following conclusions: the sensory experience, emotional experience, action experience and related experience in consumption experience have a positive impact on brand loyalty. However, thinking experience has little influence on consumers' loyalty to the brand. The reason is that the author believes that the case selected in this survey is the selection of mobile communication brand, which has a certain monopoly in view of this industry, having some influence on the conclusion of investigation and analysis in the final.

\section{Conflicts of Interest}

The author declares no conflicts of interest regarding the publication of this paper.

\section{References}

[1] Alba, J.H. (1987) Dimensions of Consumer Expertise. Journal of Consumer Research, 13, 411-454. https://doi.org/10.1086/209080

[2] Fournier, S. and Mick, D.G. (1999) Rediscovering Satisfaction. Journal of Marketing, 63, 5-23. https://doi.org/10.1177/002224299906300403

[3] Schmitt, B.H. and Zarantonello, L. (2009) Brand Experience: What Is It? How It Measured? Does It Affect Loyalty? Journal of Marketing, 73, 52.

https://doi.org/10.1509/jmkg.73.3.052

[4] Pang, J., Guo, X.D. and Peng, Q.Q. (2007) Effects of Advertising Strategy on Consumer-Brand Relationships: A Brand Love Perspective. Frontiers of Business Research in China, 3, 59-73.

[5] Rebekan, D. and Christine, A. (2004) Surfing: An Avenue for Socially Acceptable Risk-Taking, Satisfying Needs for Sensation Seeking and Experience Seeking. Personality and Individual Differences, 36, 663-677. 
[6] Whang, Y.O., Allen, J., Sahoury, N., et al. (2004) Falling in Love with a Product : The Structure of a Romantic Consumer-Product Relationship. Advances in Consumer Research, 31, 320-327.

[7] Zhang, H.M. (2003) Brand Experience Categories and Their Marketing Implications. Business Economics and Administration, 12, 22-25. 